\title{
VOCATIONAL ASPIRATION OF THE UNDERGRADUATE STUDENTS- A STUDY
}

\author{
Bhargab Pratim Bora \\ Assistant Professor, Department of Education \\ Rangapara College, Sonitpur \\ bhargab30bora@gmail.com
}

Article History:Received:11 november 2020; Accepted: 27 December 2020; Published online: 05 April 2021

ABSTRACT: Man responds to his environment by active degree of aspiration or aversion by movement
towards or a way from flue exciting stimulus. In social life, aspiration is about one's education and occupation
plays a major role in shaping one's destiny of life. Aspirations are the target a person sets for him to achieve
which creates a 'desire' or 'will' in him. Formation of a strong desire and ambition motivates individual to strive
hard to achieve that goal. Such motivation is keenly required if one has to succeed in life. If one goes through
the education on a preferred vocation, he can get job satisfaction from the vocation and the individual shall be
well placed. Aspiration adds to the efficiency of the person by exhibiting the best in him on the job. Therefore,
before providing for education for a vocation, there is a need for planners to try to know which vocations are
aspired by the students. Here in this study, different aspects of vocational aspiration was studied with 119
sample students by using simple random sampling technique with the help of self-constructed questionnaire as a
tool.

Keywords: Vocational Aspiration, Undergraduate level

\subsection{INTRODUCTION}

Vocation of an individual is considered as a major source of satisfaction in adult life and it links to real world. It is the identity of an individual when a simple query is made about any one "who is he/she" the answer flows in terms of persons occupation. Therefore the vocation of a person is not only the means of livelihood but also the way of life. In order to succeed in a chosen vocation a realistic and pragmatic approach is highly desirable. It has become exceedingly difficult to adjust for the poorly skilled and educated individual to face challenges of the modem society. Exorbitant advancement in scientific and technological field has exerted enormous pressure on individual to sharpen and substantiate the occupational competencies. Undoubtedly, the education imparted to a child which is commensurate with the interest and abilities can prepare for the right vocation to meet the contemporary challenges. There is a great need to match the education imparted to the students with their endowed potential. Education is nothing but the preparation of an individual for the "World of Work". Vegetative growth in Academics without realistic vocational goal, which is not in accordance with one's abilities, interests and aptitude, can be responsible for the dropout at the later stages. Social and national progress can be augmented by means of productive education. Peace and prosperity has been perceived as a proliferation of productive society from time immemorial. The chaos among the educated youths is apparently visible as they are not able to secure economic better off. Growing stress to cope with galloping demands of efficiency is no more secrets, which is further growing exponentially.

\subsection{CONCEPT OF VOCATIONAL ASPIRATION}

Vocational aspirations are aspects of behavior which are internally derived manifestation through directed and selected choices within the environment and influenced by psychological and socio-environmental factors. Man responds to his environment by active degree of aspiration or aversion by movement towards or a way from flue exciting stimulus. In social life, aspiration is about one's education and occupation plays a major role in shaping one's destiny of life. Aspirations are the target a person sets for him to achieve which creates a 'desire' or 'will' in him. Formation of a strong desire and ambition motivates individual to strive hard to achieve that goal. Such motivation is keenly required if one has to succeed in life. If one goes through the education on a preferred vocation, he can get job satisfaction from the vocation and the individual shall be well placed. Aspiration adds to the efficiency of the person by exhibiting the best in him on the job. Therefore, before providing for education for a vocation, there is a need for planners to try to know which vocations are aspired by the students.

*Corresponding author: Bhargab Pratim Bora 


\subsection{REVIEW OF RELATED LITERATURE}

Kaur (1990) studied "Educational and Vocational Aspirations of students belonging to Different Socioeconomic locales of Jammu Division". In this study, it was found that both educational and vocational aspirations are influenced by sex, socio-economic standard and locality. Urban students differed 84 significantly from their rural counter parts in their educational preferences and vocational aspirations. While rural students were found to aspire for high academic degree / a degree in arts, the urban students aspired for high professional degree / a degree in science.

Luchembe (1992) conducted a study on "Attitude towards skill training and Occupational Aspiration of participants in schools for continuing education." 6 schools for continuing education were randomly selected for investigation; 3 from rural and 3 from urban areas. Findings of the study revealed that except for level of education, socio economic status and environmental location of training schools did not have a significant relationship with participant's attitude towards skill training. Result also indicated that neither socio-economic status nor environmental location of training school had any significantly relationship with participant's occupational aspiration.

Paton, Wendy, Creed and Peter (2007) conducted a study on "Occupational aspirations and expectations of Australian adolescents". Adolescents across the five years of high school (169 females and 164 males) completed a survey which identified occupational status aspirations and expectations and RIASEC coded aspirations and expectations. As the focus of the study was to explore relationships between these traditional constructs and key career development constructs. Measures of career maturity, career indecision, self-esteem, career goals and school achievement were also completed. Discrepancies between occupational aspirations and expectations were reported and the relevance of including career development constructs into these investigations was validated. Occupational status aspirations were associated with school achievement, selfesteem, and career maturity. Students who reported achieving well at school, were more careers mature and had higher self-esteem were more likely to aspire to professional status occupations than students who held skilled status aspirations, and students who held semi-professional aspirations having more career knowledge than students who held skilled aspirations.

Saikia in the year 2008 in his book "Youth and Career Aspiration" gives importance on career aspiration of college going rural youths. From the investigation, it was clearly observed that though respondents show their aspiration for career, majority of the respondents' show their aspiration to teaching profession and it was thought to be very prestigious profession in the society. In the present study, it was also found that there was no more difference in educational and career aspiration.

Kalita (2013) conducted a study on Academic Performance in relation to Institutional Facilities and Career Expectations of Mising students. In his study he took 500 Mishing Secondary School students of Jorhat and Lakhimpur district. Regarding the findings related to Career Expectation the study revealed that most of the Mising Secondary School students have average level of career expectation.

\subsection{STATEMENT OF THE STUDY}

The statement of the study is -VOCATIONAL ASPIRATION OF THE UNDERGRADUATE STUDENTS-A STUDY

\subsection{AREA OF THE STUDY}

Geographically, South Kamrup stands on the southern bank of the mighty Brahmaputra of Assam. According to the Census report (2011) the population of south Kamrup is 811805. There are total 5 Provincialised govt. colleges in South Kamrup area.

\subsection{RATIONALE OF THE STUDY}

1) Failure in one occupation has a greater demoralizing effect on an individual. In the crucial period of adolescence many formative forces related to psychological and social factors affect the growing individual. The urgent need of greater understanding of the factors which influence the occupational aspirations of young people prompted this study.

2) The undergraduate stage is the crucial period where students can finally make themselves ready to enter in a vocation. They are at the turning point in which they have to take decision with regard to their vocation which is related to the stream they have already chosen. In the process of their selection of career as well as educational goal, their Vocational aspiration plays the vital role. Thus, the researcher has taken up the Undergraduate students to study their Vocational aspiration.

3) Vocational aspiration always has an inter link with the economical development of a country. It helps in building work culture, develops positive attitude towards dignity of labour which contributes in 
forming a democratic country. Development of a country depends upon the status of its every citizen and aspires for correct vocation enforces the youth in optimum utilization of their capabilities.

4) Vocational aspiration is a psychological characteristic which is influenced by different social factors. Specially, economic condition of family, parents' educational status, parents' occupation etc affects the aspiration of the college going youth. Therefore the study carried out for find out whether those factors have relation with vocational aspiration.

5) The area of the study South Kamrup is a part of rural Kamrup. As a rural area it has always been isolated from different educational schemes, programmes, and facilities of govt. in time to time. So it is necessary to explore the vocational aspiration of the college going youth of those areas.

From the above justification it can be said that the study on vocational aspiration of undergraduate students is very important.

\subsection{OBJECTIVES OF THE STUDY}

The objectives of the study are as follows-

1) To study the types of vocational aspiration of the undergraduate students studying in the colleges of South Kamrup area.

2) To study the types of vocational aspiration of the undergraduate students studying in the colleges of South Kamrup area in terms of gender.

3) To study the different determinants of vocational aspiration of the undergraduate students studying in the colleges of South Kamrup area.

4)

\subsection{OPERATIONAL DEFINITION OF THE KEY TERMS USED IN THE STUDY}

8.1 Vocational Aspiration

Vocational Aspiration refers the level of aspiration of a person to achieve a particular job or profession or Vocation. (Oxford English Dictionary, Volume $7^{\text {th }}$ Edition)

In the present study, Vocational aspiration is interpreted as the responses collected through the Questionnaire constructed by the investigator.

\subsection{Undergraduate Students}

Undergraduate level is post Secondary education up to level of Bachelor Degree. It includes all the Academic Programmes up to the level of a Bachelor Degree (B.A., B.Sc., B.Com. etc)

Here, the present study covers only the $5^{\text {th }}$ semester Science stream students studying in colleges of South Kamrup Area.

\subsection{DELIMITATION OF THE STUDY}

The delimitation of the study is as follows-

1) The study is delimited to the $5^{\text {th }}$ semester Science stream students only.

2) There are many determinants of Vocational aspiration. But in this study only following are taken-

a) Personal preference

b) Difficulties in aspiring for desired Vocation

c) Father's/Mother's Educational status

d) Father's/Mother's occupation

e) Annual income of the family

f)

10.0 METHOD USED IN THE STUDY

For the present study Descriptive Survey Method was adopted.

\subsection{POPULATION AND SAMPLE OF THE STUDY}

The all colleges of the South Kamrup area are the population of the study. For the study 2 colleges were randomly selected. There are total 394 students were enrolled in $5^{\text {th }}$ semester of Science stream of those 2 colleges. Out of that 119 students were selected by adopting simple random sampling technique. Among them 61 were boys and 58 were girls.

\subsection{TOOL USED IN THE STUDY}

Self constructed Questionnaire was used for collecting the data from the sampled students.

13.0 ANALYSIS AND INTERPRETATION

Analysis of Objective 1- Types of Vocational Aspiration

\section{Table 1.0}

Preferred Vocation of the respondent

$\begin{array}{llll}\text { Sl. Types of Vocation } & \text { Number of } & \text { Percentage }\end{array}$




\begin{tabular}{cccc}
\hline No. & & Respondents \\
\hline $\mathbf{1}$ & Legal Practice & $\mathbf{5}$ & $\mathbf{4 . 2 0 \%}$ \\
\hline $\mathbf{2}$ & Teaching Profession & $\mathbf{4 0}$ & $\mathbf{3 3 . 6 1 \%}$ \\
\hline $\mathbf{3}$ & Medical Profession & $\mathbf{2}$ & $\mathbf{1 . 6 8 \%}$ \\
\hline $\mathbf{4}$ & Engineering & $\mathbf{9}$ & $\mathbf{7 . 5 6 \%}$ \\
\hline $\mathbf{5}$ & Air service & $\mathbf{1 0}$ & $\mathbf{8 . 4 0 \%}$ \\
\hline $\mathbf{6}$ & Architecture & $\mathbf{3}$ & $\mathbf{2 . 5 3 \%}$ \\
\hline $\mathbf{7}$ & Business & $\mathbf{3}$ & $\mathbf{2 . 5 3 \%}$ \\
\hline $\mathbf{8}$ & Govt. Service & $\mathbf{3 7}$ & $\mathbf{3 1 . 0 9 \%}$ \\
\hline $\mathbf{9}$ & Sports/Literary/Art/Music/Social Service & $\mathbf{1 0}$ & $\mathbf{8 . 4 0 \%}$ \\
\hline $\mathbf{1 0}$ & Others & $\mathbf{0}$ & $\mathbf{0}$ \\
\hline & Total & $\mathbf{1 1 9}$ & $\mathbf{1 0 0 \%}$ \\
\hline
\end{tabular}

The above table shows that $33.61 \%$ college students have aspired for Teaching profession vocation which is highest in number. 31.09\% students have preferred Govt. service as their aspired vocation. The rest students have given preference to the other vocations as Air plane service (8.40\%), Sports/Literary/Art/Music/Social Service (8.40\%), Engineering (7.56\%), Legal Practice (4.20\%), Business (2.53\%) and Architecture (2.53\%).

Analysis of Objective 2- Types Vocational Aspiration in terms of gender

Table 2.0

Preferred Vocation of the respondent in terms of Gender

\begin{tabular}{cccccc}
\hline $\begin{array}{c}\text { Sl. } \\
\text { No. }\end{array}$ & Types of Vocation & $\begin{array}{c}\text { Number of } \\
\text { Boys }\end{array}$ & Percentage & $\begin{array}{c}\text { Number } \\
\text { of Girls }\end{array}$ & Percentage \\
\hline $\mathbf{1}$ & Legal Practice & $\mathbf{4}$ & $\mathbf{6 . 5 6 \%}$ & $\mathbf{1}$ & $\mathbf{1 . 7 2 \%}$ \\
\hline $\mathbf{2}$ & Teaching Profession & $\mathbf{1 1}$ & $\mathbf{1 8 . 0 3 \%}$ & $\mathbf{2 9}$ & $\mathbf{5 0 \%}$ \\
\hline $\mathbf{3}$ & Medical Profession & $\mathbf{1}$ & $\mathbf{1 . 6 4 \%}$ & $\mathbf{1}$ & $\mathbf{1 . 7 2 \%}$ \\
\hline $\mathbf{4}$ & Engineering & $\mathbf{8}$ & $\mathbf{1 3 . 1 1 \%}$ & $\mathbf{1}$ & $\mathbf{1 . 7 2 \%}$ \\
\hline $\mathbf{5}$ & Air plane service & $\mathbf{5}$ & $\mathbf{8 . 2 0 \%}$ & $\mathbf{5}$ & $\mathbf{8 . 6 2 \%}$ \\
\hline $\mathbf{6}$ & Architecture & $\mathbf{2}$ & $\mathbf{3 . 2 8} \%$ & $\mathbf{1}$ & $\mathbf{1 . 7 2 \%}$ \\
\hline $\mathbf{7}$ & Business & $\mathbf{1}$ & $\mathbf{1 . 6 4 \%}$ & $\mathbf{2}$ & $\mathbf{3 . 4 5 \%}$ \\
\hline $\mathbf{8}$ & Govt. Service & $\mathbf{2 2}$ & $\mathbf{3 6 . 0 7 \%}$ & $\mathbf{1 5}$ & $\mathbf{2 5 . 8 6 \%}$ \\
\hline $\mathbf{9}$ & Sports/Literary/Art/Music/Social & $\mathbf{7}$ & $\mathbf{1 1 . 4 8 \%}$ & $\mathbf{3}$ & $\mathbf{5 . 1 7 \%}$ \\
\hline $\mathbf{1 0}$ & Service & $\mathbf{0}$ & $\mathbf{0}$ & $\mathbf{0}$ & $\mathbf{0}$ \\
\hline & Others & $\mathbf{6 1}$ & & $\mathbf{5 8}$ \\
\hline
\end{tabular}

The above table reveals that $50 \%$ girl students have preferred teaching profession and $36.07 \%$ boy students have preferred Govt. service as their aspired vocation. Again $18.03 \%$ boys have preferred teaching profession and $25.86 \%$ girls have preferred Govt. service. The other students preferred the other vocations.

Analysis of Objective 3- Different determinants of vocational aspiration

Table 3.0

Main considerations for preferred Vocation

\begin{tabular}{cccccc}
\hline $\begin{array}{c}\text { Sl. } \\
\text { No. }\end{array}$ & Considerations & $\begin{array}{c}\text { Number of } \\
\text { Boys }\end{array}$ & Percentage & $\begin{array}{c}\text { Number of } \\
\text { Girls }\end{array}$ & Percentage \\
\hline $\mathbf{1}$ & High Income & $\mathbf{2 7}$ & $\mathbf{4 4 . 2 6 \%}$ & $\mathbf{2 4}$ & $\mathbf{4 1 . 3 8 \%}$ \\
\hline $\mathbf{2}$ & $\begin{array}{c}\text { High Prestige and } \\
\text { Status }\end{array}$ & $\mathbf{2 3}$ & $\mathbf{3 7 . 7 0 \%}$ & $\mathbf{1 5}$ & $\mathbf{2 5 . 8 6 \%}$ \\
\hline $\mathbf{3}$ & $\begin{array}{c}\text { Peaceful life and } \\
\text { comfort work }\end{array}$ & $\mathbf{3}$ & $\mathbf{4 . 9 2 \%}$ & $\mathbf{2}$ & $\mathbf{3 . 4 5 \%}$ \\
\hline $\mathbf{4}$ & Security of life & $\mathbf{5}$ & $\mathbf{8 . 2 0 \%}$ & $\mathbf{1 1}$ & $\mathbf{1 8 . 9 7 \%}$ \\
\hline $\mathbf{5}$ & $\begin{array}{c}\text { Opportunity to } \\
\text { show one's own } \\
\text { talent }\end{array}$ & $\mathbf{3}$ & $\mathbf{4 . 9 2 \%}$ & $\mathbf{6}$ & $\mathbf{1 0 . 3 4 \%}$ \\
\hline & Total & $\mathbf{6 1}$ & $\mathbf{1 0 0 \%}$ & $\mathbf{5 8}$ & $\mathbf{1 0 0 \%}$ \\
\hline
\end{tabular}

By analyzing the Table 4.0 , it is found that $44.26 \%$ boys and $41.38 \%$ girls are favour of high income, $37.70 \%$ boys and $25.86 \%$ girls are favour of high prestige and status. The rest students have chosen the other options like peaceful life and comfort work, Security of life and opportunity to show one's own talent. 
Table 4.0

Difficulties of aspiring for desired Vocation

\begin{tabular}{cccccc}
\hline $\begin{array}{c}\text { Sl. } \\
\text { No. }\end{array}$ & Difficulties & $\begin{array}{c}\text { Number of } \\
\text { Boys }\end{array}$ & Percentage & $\begin{array}{c}\text { Number of } \\
\text { Girls }\end{array}$ & Percentage \\
\hline $\mathbf{1}$ & Economic factor & $\mathbf{1 1}$ & $\mathbf{1 8 . 0 3 \%}$ & $\mathbf{9}$ & $\mathbf{1 5 . 5 2 \%}$ \\
\hline $\mathbf{2}$ & Social factor & $\mathbf{1 6}$ & $\mathbf{2 6 . 2 3 \%}$ & $\mathbf{2 1}$ & $\mathbf{3 6 . 2 1 \%}$ \\
\hline $\mathbf{3}$ & $\begin{array}{c}\text { Lack of family } \\
\text { support }\end{array}$ & $\mathbf{1 2}$ & $\mathbf{1 9 . 6 7 \%}$ & $\mathbf{2 0}$ & $\mathbf{3 4 . 4 8 \%}$ \\
& Lack of Inspiration & $\mathbf{2 2}$ & $\mathbf{3 6 . 0 7 \%}$ & $\mathbf{8}$ & $\mathbf{1 3 . 7 9 \%}$ \\
\hline $\mathbf{4}$ & Any other & $\mathbf{0}$ & $\mathbf{0}$ & $\mathbf{0}$ & $\mathbf{0}$ \\
\hline $\mathbf{5}$ & Total & $\mathbf{6 1}$ & $\mathbf{1 0 0 \%}$ & $\mathbf{5 8}$ & $\mathbf{1 0 0 \%}$ \\
\hline
\end{tabular}

The above table shows that $36.07 \%$ boys face difficulties of aspiring for desired vocation due to lack inspiration, $26.23 \%$ face difficulties due to social factor, $19.67 \%$ face difficulties due to Lack of family support and $18.03 \%$ face difficulties due to Economic factor. Again $13.79 \%$ girls face difficulties of aspiring for desired vocation due to lack inspiration, $36.21 \%$ face difficulties due to social factor, $34.48 \%$ face difficulties due to Lack of family support and $15.52 \%$ face difficulties due to Economic factor.

Table 5.0

Father's/Mother's level of Education and Respondents aspiration for Vocation

\begin{tabular}{|c|c|c|c|c|c|c|c|c|c|c|}
\hline \multirow{2}{*}{$\begin{array}{c}\text { Father's/Moth } \\
\text { er's } \\
\text { Level of } \\
\text { Education }\end{array}$} & \multicolumn{7}{|c|}{ Types of Vocation } & & & \\
\hline & $\begin{array}{c}\text { Legal } \\
\text { Practice }\end{array}$ & $\begin{array}{c}\text { Teachi } \\
\text { ng } \\
\text { Professi } \\
\text { on }\end{array}$ & $\begin{array}{c}\text { Medica } \\
1 \\
\text { Service }\end{array}$ & $\begin{array}{c}\text { Engine } \\
\text { ering }\end{array}$ & $\begin{array}{c}\text { Air } \\
\text { Servic } \\
\text { e }\end{array}$ & $\begin{array}{l}\text { Archit } \\
\text { ecture }\end{array}$ & $\begin{array}{c}\text { Busin } \\
\text { ess }\end{array}$ & $\begin{array}{c}\text { Govt. } \\
\text { Service }\end{array}$ & $\begin{array}{c}\text { Sports/A } \\
\text { rt/Music } \\
\text { /Social } \\
\text { Service }\end{array}$ & $\begin{array}{c}\text { Tot } \\
\text { al }\end{array}$ \\
\hline Illiterate & 0 & $\begin{array}{c}4 \\
(36 \%)\end{array}$ & 0 & 0 & 0 & 0 & $\begin{array}{c}1 \\
(9 \%)\end{array}$ & $\begin{array}{c}4 \\
(36)\end{array}$ & $\begin{array}{c}2 \\
(18 \%)\end{array}$ & 11 \\
\hline Class I-IV & 0 & $\begin{array}{c}2 \\
(28 \%)\end{array}$ & 0 & 0 & 0 & 0 & 0 & $\begin{array}{c}5 \\
(71 \%)\end{array}$ & 0 & 7 \\
\hline $\mathbf{V}-\mathbf{X}$ & 0 & $\begin{array}{c}2 \\
(25 \%)\end{array}$ & 0 & 0 & 0 & 0 & 0 & $\begin{array}{c}6 \\
(75 \%)\end{array}$ & 0 & 8 \\
\hline H.S & 0 & $\begin{array}{c}10 \\
(41 \%) \\
\end{array}$ & 0 & 0 & 0 & 0 & 0 & $\begin{array}{c}10 \\
(41 \%)\end{array}$ & $\begin{array}{c}4 \\
(18 \%)\end{array}$ & 24 \\
\hline Graduate & $\begin{array}{c}5 \\
(9 \%)\end{array}$ & $\begin{array}{c}16 \\
(31 \%)\end{array}$ & 0 & $\begin{array}{c}4 \\
(7 \%)\end{array}$ & $\begin{array}{c}10 \\
(19 \%)\end{array}$ & $\begin{array}{c}1 \\
(2 \%)\end{array}$ & $\begin{array}{c}2 \\
(4 \%)\end{array}$ & $\begin{array}{c}12 \\
(23 \%)\end{array}$ & $\begin{array}{c}1 \\
(2 \%)\end{array}$ & 51 \\
\hline PG & 0 & $\begin{array}{c}6 \\
(33 \%)\end{array}$ & $\begin{array}{c}2 \\
(11 \%)\end{array}$ & $\begin{array}{c}5 \\
(27 \%)\end{array}$ & 0 & $\begin{array}{c}2 \\
(11 \%)\end{array}$ & 0 & 0 & $\begin{array}{c}3 \\
(6 \%)\end{array}$ & 18 \\
\hline Total & 5 & 40 & 2 & 9 & 10 & 3 & 3 & 37 & 10 & 119 \\
\hline
\end{tabular}

By analyzing the above table it is found that among the 119 students 11 parents of them are illiterate where $36 \%$ respondents aspire for teaching profession and govt. service and $9 \%$ aspire for business and $18 \%$ aspire for sports/art/music/social service. Again 51 parents are graduates where $27 \%$ girls aspire for teaching profession and $20 \%$ boys aspires for business, $10 \%$ boys and girls aspire for air plane service. Moreover 24 parents are parents are H.S passed whose $25 \%$ boys aspire for teaching profession, $20 \%$ boys and girls aspire for govt. service and $16 \%$ girls aspire for teaching profession. 18 parents are Post graduates whose $16 \%$ boys aspire for sports/art/music/social service, $22 \%$ aspire for engineering and $28 \%$ girls aspire for teaching profession, $5 \%$ aspire for medical, engineering service etc. Again, 8 parents are passed V-X class whose $37 \%$ boys and girls aspire for govt. services and 7 parents are passed I-IV whose $42 \%$ boys aspire for govt. service and $28 \%$ girls aspire for teaching profession and govt. service. 
Table 6.0

Father's/Mother's Occupation and Respondents aspiration for Vocation

\begin{tabular}{|c|c|c|c|c|c|c|c|c|c|c|}
\hline & & & & & Type & of Voce & ion & & & \\
\hline $\begin{array}{c}\text { Fathe } \\
\text { r's/M } \\
\text { other } \\
\text { 's } \\
\text { Occu } \\
\text { patio } \\
\text { n }\end{array}$ & $\begin{array}{c}\text { Legal } \\
\text { Pract } \\
\text { ice }\end{array}$ & $\begin{array}{c}\text { Teac } \\
\text { hing } \\
\text { Profe } \\
\text { ssion }\end{array}$ & $\begin{array}{l}\text { Medi } \\
\text { cal } \\
\text { Profe } \\
\text { ssion }\end{array}$ & $\begin{array}{c}\text { Engi } \\
\text { neeri } \\
\text { ng }\end{array}$ & $\begin{array}{c}\text { Air } \\
\text { Servi } \\
\text { ce }\end{array}$ & $\begin{array}{c}\text { Arch } \\
\text { itect } \\
\text { ure }\end{array}$ & $\begin{array}{c}\text { Busin } \\
\text { ess }\end{array}$ & $\begin{array}{c}\text { Govt. } \\
\text { Servic } \\
\text { e }\end{array}$ & $\begin{array}{c}\text { Sports/ } \\
\text { Art/M } \\
\text { usic/So } \\
\text { cial } \\
\text { Service }\end{array}$ & $\begin{array}{l}\text { To } \\
\text { tal }\end{array}$ \\
\hline $\begin{array}{c}\text { Farm } \\
\text { er }\end{array}$ & $\mathbf{0}$ & $\begin{array}{c}2 \\
(27 \% \\
)\end{array}$ & $\mathbf{0}$ & 0 & $\mathbf{0}$ & 0 & $\begin{array}{c}1 \\
(5 \%)\end{array}$ & $\begin{array}{c}11 \\
(61 \%)\end{array}$ & $\begin{array}{c}4 \\
(22 \%)\end{array}$ & 18 \\
\hline LP & $\begin{array}{c}4 \\
(40 \% \\
\quad)\end{array}$ & $\begin{array}{c}1 \\
(10 \% \\
)\end{array}$ & $\mathbf{0}$ & $\begin{array}{c}1 \\
(10 \% \\
)\end{array}$ & $\begin{array}{c}3 \\
(30 \% \\
) \\
\end{array}$ & 0 & $\mathbf{0}$ & $\begin{array}{c}1 \\
(10 \%)\end{array}$ & $\mathbf{0}$ & 10 \\
\hline TP & $\mathbf{0}$ & $\begin{array}{c}21 \\
(68 \% \\
\quad) \\
\end{array}$ & $\mathbf{0}$ & $\begin{array}{c}1 \\
(3 \%)\end{array}$ & $\mathbf{0}$ & $\mathbf{0}$ & $\mathbf{0}$ & $\begin{array}{c}7 \\
(22 \%)\end{array}$ & $\begin{array}{c}2 \\
(6 \%)\end{array}$ & 31 \\
\hline MP & $\mathbf{0}$ & $\begin{array}{c}3 \\
(30 \% \\
)\end{array}$ & $\begin{array}{c}2 \\
(20 \% \\
)\end{array}$ & 0 & $\begin{array}{c}4 \\
(40 \% \\
\quad)\end{array}$ & 0 & 0 & $\begin{array}{c}1 \\
(10 \%)\end{array}$ & 0 & 10 \\
\hline ENG & $\mathbf{0}$ & $\begin{array}{c}2 \\
(16 \% \\
) \\
\end{array}$ & 0 & $\begin{array}{c}4 \\
(33 \% \\
\quad) \\
\end{array}$ & $\begin{array}{c}2 \\
(16 \% \\
) \\
\end{array}$ & $\begin{array}{c}3 \\
(25 \\
\%) \\
\end{array}$ & $\mathbf{0}$ & $\begin{array}{c}1 \\
(8 \%)\end{array}$ & $\mathbf{0}$ & 12 \\
\hline BSS & 0 & $\begin{array}{c}1 \\
(12 \% \\
) \\
\end{array}$ & 0 & $\begin{array}{c}1 \\
(12 \% \\
) \\
\end{array}$ & $\begin{array}{c}1 \\
(12 \% \\
) \\
\end{array}$ & 0 & $\begin{array}{c}2 \\
(25 \%)\end{array}$ & $\begin{array}{c}1 \\
(12 \%)\end{array}$ & $\begin{array}{c}2 \\
(25 \%)\end{array}$ & 8 \\
\hline GS & $\begin{array}{c}1 \\
(3 \%)\end{array}$ & $\begin{array}{c}7 \\
(26 \% \\
) \\
\end{array}$ & $\mathbf{0}$ & $\begin{array}{c}2 \\
(7 \%)\end{array}$ & 0 & $\mathbf{0}$ & $\mathbf{0}$ & $\begin{array}{c}15 \\
(55 \%)\end{array}$ & $\begin{array}{c}2 \\
(7 \%)\end{array}$ & 27 \\
\hline OTH & $\mathbf{0}$ & $\begin{array}{c}3 \\
(100 \\
\%)\end{array}$ & $\mathbf{0}$ & $\mathbf{0}$ & 0 & 0 & 0 & 0 & $\mathbf{0}$ & 3 \\
\hline Total & 5 & 40 & 2 & 9 & 10 & 3 & 3 & 37 & 10 & $\begin{array}{c}11 \\
9 \\
\end{array}$ \\
\hline
\end{tabular}

The above table shows that 18 parents of the students are farmer by their occupation. Among them $28 \%$ boys and $33 \%$ girls aspire for govt. service, 5\% aspire for teaching profession. Again 10 parents are engaged in legal practice whose $30 \%$ boys aspire for legal practice and air plane service, $10 \%$ girls aspire for teaching profession, legal practice, engineering and govt. service. Apart from that 31 parents are engaged in teaching profession whose $48 \%$ girls aspire for teaching profession, $19 \%$ boys aspire for teaching profession and govt. service. Moreover 10 parents are engaged in medical service whose $40 \%$ girls aspire for air plane service, $20 \%$ aspire for teaching profession, $10 \%$ boys aspire for legal practice, medical profession etc., 12 parents are engaged in engineering profession whose $33 \%$ boys aspire for engineering profession, $16 \%$ girls aspire for teaching profession. The rest 8 parents are engaged in business, 27 are in govt. service and 3 in other professions. 
Table 7.0

Annual Income of family and Respondents aspiration for Vocation

\section{Types of Vocation}

\begin{tabular}{|c|c|c|c|c|c|c|c|c|c|}
\hline $\begin{array}{l}\text { Annual } \\
\text { income }\end{array}$ & $\begin{array}{c}\text { Legal } \\
\text { Practi } \\
\text { ce }\end{array}$ & $\begin{array}{l}\text { Teachi } \\
\text { ng } \\
\text { Profes } \\
\text { sion }\end{array}$ & $\begin{array}{c}\text { Medi } \\
\text { cal } \\
\text { Profe } \\
\text { ssion }\end{array}$ & $\begin{array}{c}\text { Engin } \\
\text { eerin } \\
\mathbf{g}\end{array}$ & $\begin{array}{c}\text { Air } \\
\text { Service }\end{array}$ & $\begin{array}{l}\text { Archit } \\
\text { ecture }\end{array}$ & $\begin{array}{c}\text { Busine } \\
\text { sS }\end{array}$ & $\begin{array}{c}\text { Govt. } \\
\text { Servi } \\
\text { ce }\end{array}$ & $\begin{array}{c}\text { Sport } \\
\text { s/Art/ } \\
\text { Musi } \\
\text { c/Soci } \\
\text { alSer } \\
\text { vice }\end{array}$ \\
\hline
\end{tabular}

\begin{tabular}{|c|c|c|c|c|c|c|c|c|c|c|}
\hline $\begin{array}{c}\text { Below } \\
10,000\end{array}$ & $\mathbf{0}$ & $\begin{array}{c}3 \\
(15 \%)\end{array}$ & $\overline{\mathbf{0}}$ & $\overline{\mathbf{0}}$ & $\mathbf{0}$ & $\mathbf{0}$ & $\begin{array}{c}1 \\
(5 \%)\end{array}$ & $\begin{array}{c}12 \\
(60 \% \\
)\end{array}$ & $\begin{array}{c}4 \\
(20 \% \\
)\end{array}$ & 20 \\
\hline $\begin{array}{c}10,000- \\
25000\end{array}$ & $\begin{array}{c}4 \\
(6 \%)\end{array}$ & $\begin{array}{c}26 \\
(42 \%)\end{array}$ & 0 & $\begin{array}{c}2 \\
(3 \%)\end{array}$ & $\begin{array}{c}3 \\
(5 \%)\end{array}$ & $\mathbf{0}$ & $\begin{array}{c}2 \\
(3 \%)\end{array}$ & $\begin{array}{c}20 \\
(33 \% \\
) \\
\end{array}$ & $\begin{array}{c}4 \\
(6 \%)\end{array}$ & 61 \\
\hline $\begin{array}{c}25000- \\
50000\end{array}$ & $\begin{array}{c}1 \\
(3 \%)\end{array}$ & $\begin{array}{c}11 \\
(32 \%)\end{array}$ & 0 & $\begin{array}{c}6 \\
(17 \% \\
)\end{array}$ & $\begin{array}{c}7 \\
(20 \%)\end{array}$ & $\begin{array}{c}3 \\
(9 \%)\end{array}$ & 0 & $\begin{array}{c}5 \\
(14 \% \\
)\end{array}$ & $\begin{array}{c}1 \\
(3 \%)\end{array}$ & 34 \\
\hline $\begin{array}{c}\mathbf{5 0 0 0 0} \\
\& \\
\text { Above } \\
\end{array}$ & 0 & 0 & $\begin{array}{c}2 \\
(50 \% \\
)\end{array}$ & $\begin{array}{c}1 \\
(25 \% \\
) \\
\end{array}$ & 0 & 0 & $\mathbf{0}$ & $\mathbf{0}$ & $\begin{array}{c}1 \\
(25 \% \\
)\end{array}$ & 4 \\
\hline Total & 5 & 40 & 2 & 9 & 10 & 3 & 3 & 37 & 10 & $\begin{array}{c}11 \\
9\end{array}$ \\
\hline
\end{tabular}

By analyzing the above table it is found that 20 families of the respondents earn below 10,000 rupees per month whose $30 \%$ boys and girls aspire for govt. service, $10 \%$ girls aspire for teaching profession. Again 61 families of the respondent earn between 10,000-25000 rupees per month whose $31 \%$ girls aspire for teaching profession, $11 \%$ aspire for govt. service, $21 \%$ boys aspire for govt. service, $11 \%$ boys aspire for teaching profession etc. Moreover 34 families earn 25000-50000 rupees per month whose 23\% girls aspire for teaching profession, $3 \%$ girls aspire for engineering, $14 \%$ girls aspire for air services, $9 \%$ boys aspire for teaching profession, $14 \%$ for engineering, $6 \%$ for air services etc. Apart from that only 4 families earn above 50,000 rupees per month whose $25 \%$ boys aspires for medical and engineering service and $25 \%$ girls aspire for medical and sports/art/music/social services.

\subsection{FINDINGS OF THE STUDY}

The findings of the study are as follows-

1) The study reveals that most of the respondents (33.61\%) have vocational aspiration towards teaching profession. Again 31.09\% respondents have vocational aspiration towards govt. service. It is remarkable that very less respondents have found who have vocational aspiration towards Medical profession, engineering, legal practice etc.

2) It has been found that in terms of gender most of the girls (50\%) have vocational aspiration towards teaching profession and most of the boys have vocational aspiration towards govt. service. Apart from that it has also been found that very less boys and girls have vocational aspiration towards medical profession, architecture, legal practice etc.

3) It has also been found that most of the boys (44.26\%) and girls (41.28\%) respondents are favour of high income for choosing vocation. Again $37.70 \%$ boys and $27.86 \%$ girls have chosen vocation as a consideration of high prestige and status.

4) From the study it has been found that most of the boys (36.07\%) face difficulty as aspiring for desired vocation due to lack of inspiration and most of the girls (34.48\%) face difficulty as aspiring for desired vocation due to social factor. Again $34.48 \%$ girls face difficulty due to lack of family support as aspiring for desired vocation.

5) Most of the respondents have vocational aspiration towards teaching profession and govt. service whose parents read up to higher secondary level. But on the other hand the respondent of graduate and 
post graduate parents have vocational aspiration towards medical service, engineering, air services, teaching profession and govt. service.

6) In the study some similarity has found in terms of parents occupation and respondents vocational aspiration. It has been found that most of the respondents $(61 \%)$ aspire for govt. service whose fathers' occupation is farming. Again most of the respondent which is $40 \%$ aspires for legal practice, $68 \%$ for teaching profession, $25 \%$ for business, $33 \%$ for engineering and 55\% for govt. service whose parents are engaged in same occupation. Apart from that $40 \%$ respondents have chosen air service and all respondents have chosen teaching profession whose parents are engaged in medical service and other occupation respectively.

7) It has been found that majority of respondents (60\%) have preferred govt. service whose family income below 10,000 and most of the respondent have preferred teaching profession whose family income is 10,000-50,000 rupees per month. Apart from that majority of the respondents $(50 \%)$ have preferred medical service whose family income is above 50,000 rupees per month.

\subsection{SUGESSIONS OF THE STUDY}

1) Guidance and Counseling cell should be established in every colleges and it should be provided regularly. Through Guidance and Counselling they can be assisted to set high aspiration towards appropriate vocation according to their abilities and potentialities because higher educational institution plays an important role in shaping the personality of the students and making skillful and productive human resource.

2) Parents should always aware about their children's aspiration for future occupation. If a child has low level of vocational aspiration, the parents should analyze their problems and try to provide proper environment that children can form higher aspiration.

3) A teacher can create a simulative environment in the college and classroom so that the children can develop their aspiration. The role of the teacher provides the child encouragement, support and cooperation in directing and controlling his development of career.

4) Though the students belong to low social status enter the colleges, the teacher should make an effort to convince that their low social status has nothing to do with their personality and academic achievement. All the teachers should treat the students alike irrespective of their social status background and provide special attention to the children coming from low and middle social status to develop self-confidence in realizing their potentialities in accordance to their vocational aspirations.

5) Parents' educational status, occupation and economic status are some factors which play role as determinants in forming the vocational aspiration of the undergraduate students. So it's a responsibility of the parents, government and teachers to make free the youth from those factors and letting them aspire for dream vocation according to their potentialities.

\subsection{CONCLUSION}

Social and national progress can be augmented by means of productive Higher education. Peace and prosperity has been perceived as a proliferation of productive society from time immemorial. Vocational aspiration is related to the future work and as well as the economic status of an individual. And economic status, economic independency of each individual is directly related to the progress of a democratic country.

\section{REFERENCES}

Kalita, U.(2013). Academic performance in relation to Institutional facilities and career expectations of Mishing students- A Study. (Unpublished Doctoral thesis, Gauhati University)

Kothari, C.R. (2004). Research Methodology: Methods and Techniques. New Delhi: New age International Publishers.

Koul, L. (2009). Methodology of Educational Research. New Delhi: Vikash Publication House Pvt. Ltd.

Mangal, S. K. (2014). Statistics in Psychology and Education. Delhi: Phi Learning private Ltd.

Patton, Wendy, A., \& Creed, P. (2007). Occupational aspiration and expectations of Australian adolescents. Australian journal for career development. 16(1), 46-59. Retrieved from http://eprints.qut.edu.au, accessed on 9/20/2015 at 9:42 p.m.

Saikia, J.P. (2008). Youth and Career Aspiration. Guwahati: DVS Publishers.

Shahid, H.M.A. (1993). Some Aspects of Ecological and Human Characteristics of the Brahmaputra Char areas, Assam: Institute of Social changes and Development. 